\title{
Erratum to: Douglas W. Allen: The institutional revolution: measurement and the economic emergence of the modern world
}

\section{Chicago, IL: The University of Chicago Press, 2012. xiv + 267 pages. USD 30.00 (cloth)}

\section{Karen Clay}

Published online: 30 January 2014

(C) Springer Science+Business Media New York 2014

\section{Erratum to: Public Choice (2014) 158:281-283 DOI 10.1007/s11127-013-0059-9}

Due to an unfortunate turn of events this article has been published with an erroneous version of the article title. Please find on this page the correct version of the article title that should be regarded by the reader as the final version.

Douglas W. Allen: The institutional revolution: measurement and the economic emergence of the modern world

The online version of the original article can be found under doi:10.1007/s11127-013-0059-9.

K. Clay $(\bowtie)$

Heinz College, Carnegie Mellon University, 4800 Forbes Avenue,

Pittsburgh, PA 15213, USA

e-mail: kclay@andrew.cmu.edu 